\title{
Grape juices produced from new hybrid varieties grown on Brazilian rootstocks - Bioactive compounds, organic acids and antioxidant capacity
}

\author{
Marlon Jocimar Rodrigues da Silva ${ }^{\mathrm{a}, *}$, Carla Valéria da Silva Padilha ${ }^{\mathrm{b}}$, Marcos dos Santos Lima ${ }^{\mathrm{b}}$, \\ Giuliano Elias Pereira ${ }^{\mathrm{c}}$, Waldemar Gastoni Venturini Filho ${ }^{\mathrm{a}}$, Mara Fernandes Moura ${ }^{\mathrm{d}}$, \\ Marco Antonio Tecchio ${ }^{a}$ \\ ${ }^{a}$ São Paulo State University (Unesp), School of Agriculture, Campus Botucatu, Avenida Universitária, $n^{\circ} 3780$ - CEP 18610-034, Altos do Paraíso, Botucatu, SP, Brazil \\ ${ }^{\mathrm{b}}$ Instituto Federal do Sertão Pernambucano, Departamento de Tecnologia em Alimentos, Campus Petrolina, Rod. BR 407 Km 08, S/N, Jardim São Paulo, CEP 56314-520 \\ Petrolina, PE, Brazil \\ ${ }^{\mathrm{c}}$ Empresa Brasileira de Pesquisa Agropecuária - Embrapa Semiárido/Uva e Vinho, Rodovia BR 428, Km 152, CP 23, CEP 56302-970 Petrolina, PE, Brazil \\ ${ }^{\mathrm{d}}$ Centro APTA de Frutas, Instituto Agronômico, Avenida Luiz Pereira do Santos, 1500, CEP 13.214-820, Jundiaí, SP, Brazil
}

\section{A R T I C L E I N F O}

\section{Keywords:}

Vitis labrusca L.

Hybrid grapes

Scion-rootstock combinations

Phenolic compounds

Resveratrol

Color measurements

\begin{abstract}
A B S T R A C T
The objective of this study was to assess the content of bioactive compounds, organic acids and antioxidant capacity of grape juices from Isabel Precoce, BRS Carmem, BRS Cora and IAC 138-22 Máximo varieties grown on the 'IAC 766' and 'IAC 572' rootstocks under tropical conditions in Brazil. In general, the color attributes of the 'Isabel Precoce' juice were inferior to those of the other juices due to their low anthocyanin content. In contrast, 'IAC 138-22 Máximo' juices showed the highest content of most individual anthocyanins, flavonols, trans-resveratrol and total phenolic compounds, and thus, higher antioxidant capacity. Except for 'BRS Carmem', all the juices presented higher sugar accumulation when 'IAC 766' was used. This rootstock also contributed to the accumulation of $t$-resveratrol and most of individual anthocyanins in the 'IAC 138-22 Máximo' juices. However, the monomeric anthocyanin content was higher in 'BRS Carmem' juices when 'IAC 572' rootstock was used.
\end{abstract}

\section{Introduction}

The consumption of whole grape juice in Brazil increased by $570 \%$ in just 10 years, from 15.8 million liters in 2005 to 90.3 million liters in 2014 (Ibravin, 2015). The growing interest and good acceptance of grape juices by Brazilian consumers is mainly related to the several health benefits, which is due to the biological activity of the phenolic compounds present in grape juice, including antioxidant, cardioprotective, anticancer, anti-inflammatory and antimicrobial properties and subsequent benefits to human health (Granato, Carrapeiro, Fogliano, \& Van Ruth, 2016). The main phenolic compounds present include anthocyanins, flavanols, flavonols, stilbenes and phenolic acids (Lima et al., 2014).

The bioactive composition of the juice is mainly dependent on the grape used in its elaboration. Each variety has an individual phenolic composition. However, the concentration of these compounds may vary depending on a series of factors, such as the species, the cultural practices adopted in the vineyard, the climatic conditions of the region and even the maturation stage of the grape at harvest moment (Barcia,
Pertuzatti, Gómez-Alonso, Godoy, \& Hermosín-Gutiérrez, 2014; Burin, Ferreira-Lima, Panceri, \& Bordignon-Luiz, 2014; Koyama et al., 2014; Lima et al., 2014).

The cultivation of grapes for juice production in Brazil is primarily concentrated in the south region, under subtropical $(C f a)$ or temperate $(\mathrm{Cfb})$ conditions, with average annual temperatures around $17^{\circ} \mathrm{C}$. However, it has expanded to tropical regions, such as the northwest of the state of São Paulo ( $A w$ ), Brazil, located to $20^{\circ} 20^{\prime} \mathrm{S}, 49^{\circ} 58^{\prime} \mathrm{O}$, where the mean annual temperature is around $24.1^{\circ} \mathrm{C}$. This has been possible due to the development of new hybrid varieties adapted to the hottest regions in Brazil (Camargo, Maia, \& Ritschel, 2008). Among these new grapes are 'Isabel Precoce', a somatic mutation of 'Isabel' (Camargo, 2004), 'BRS Cora' and 'BRS Carmem', developed by Empresa Brasileira de Pesquisa Agropecuária (Embrapa), and the 'IAC 138-22 Máximo', developed by the Instituto Agronômico (IAC).

Brazil has also invested in the development of rootstocks adapted to the Brazilian tropical regions, combining vigor with resistance to high temperatures and the main pests and diseases associated with the grapevine. Among these rootstocks are 'IAC 766' (medium vigor) and

\footnotetext{
* Corresponding author.

E-mail addresses: marlon.silva@fca.unesp.br (M.J.R. da Silva), marcos.santos@ifsertao-pe.edu.br (M. dos Santos Lima), giuliano.pereira@embrapa.br (G.E. Pereira), venturini@fca.unesp.br (W.G.V. Filho), mouram@iac.sp.gov.br (M.F. Moura), tecchio@fca.unesp.br (M.A. Tecchio).
} 
'IAC 572' (high vigor), which were also developed by the genetic improvement program of IAC (Maia \& Camargo, 2012).

Studies have indicated that the scion-rootstock interaction can influence the quality of the grape, leading to different profiles of bioactive phenolic compounds in the grapes and, consequently, in their juices and wines (de Sá Borges, da Silva, Roberto, de Assis, \& Yamamoto, 2013; Nassur, Pereira, Alves, \& Lima, 2014; Silva et al., 2017). However, no information was found in the literature on the effects of Brazilian rootstocks on the chemical composition of grape juices produced from new grape hybrid varieties. Thus, the objective of this study was to evaluate the profile of bioactive phenolic compounds, organic acids and antioxidant capacity in grape juices produced from new hybrid varieties grown on different rootstocks.

\section{Material and methods}

\subsection{Chemicals}

Ethanol, sulfuric acid, potassium persulfate and Folin-Ciocalteu reagent were obtained from Merck (Darmstadt, Germany). Trolox (6-hydroxy-2,5,7,8-tetramethylchroman-2-carboxylic acid), 2,2-diphenyl-1picrylhydrazyl (DPPH), 2,2-azino-bis(3-ethylbenzthiazoline-6-sulfonic acid) (ABTS), glucose and fructose were obtained from Sigma-Aldrich (St. Louis, MO, USA). Methanol and acetonitrile were obtained from J.T. Backer (Mexico). Purified water was obtained from a Milli-Q ${ }^{\circledR}$ System (Millipore, Bedford, MA, USA). Malvidin 3,5-diglucoside, malvidin 3-glucoside, cyanidin 3,5-diglucoside, cyanidin 3-glucoside, peonidin 3-glucoside, delphinidin 3-glucoside, pelargonidin 3-glucoside, petunidin 3-glucoside, kaempferol 3-glucoside, myricetin, isorhamnetin 3-glucoside, quercetin (dihydrate), rutin, isoquercetin (quercetin-3-Oglucopyranoside), gallic acid, cinnamic acid, $\rho$-coumaric acid, chlorogenic acid, caffeic acid, trans-resveratrol, (-)-epicatechin gallate and (-)-epigallocatechin gallate were obtained from Extrasynthese (Genay, France). Malic, citric, lactic, acetic and tartaric acids were obtained from Vetec Chemistry Ltda (Rio de Janeiro, Brazil).

\subsection{Experimental location, grape varieties and growing conditions}

Grapes were harvested from an experimental vineyard located in Votuporanga (latitude $20^{\circ} 20^{\prime} \mathrm{S}$, longitude $49^{\circ} 58^{\prime} \mathrm{W}$; elevation $525 \mathrm{~m}$ ), northwest region of the State of São Paulo, Brazil. According to the Köppen classification, the climate is type Aw, i.e., tropical climate with dry winter. An automatic meteorological station (Campbell Scientific ${ }^{\circledR}$, Logan, UT, USA) installed in the experimental area recorded meteorological conditions during the study period. The mean temperature was $24.1{ }^{\circ} \mathrm{C}$, the minimum average was $16.6^{\circ} \mathrm{C}$ and the maximum average was $31.7^{\circ} \mathrm{C}$. The average annual rainfall was $1495 \mathrm{~mm}$, with a tendency for concentrated rainfall in the summer months. The soil was classified as Argissolo Vermelho-Amarelo (equivalent to Ultisol, USDA soil taxonomy) according to previously published criteria (Embrapa, 2006).

One Vitis labrusca L., 'Isabel Precoce', and three hybrid grapes, 'BRS Carmem' (Muscat Belly A $\times \mathrm{H}$ 65.9.14), 'BRS Cora' (Muscat Belly A $\times$ H. 65.9.14) and 'IAC 138-22 Máximo' (Seibel $11342 \times$ Syrah), were grown on the rootstocks 'IAC 766' Campinas (106-8 Mgt $\times V$. caribaea) and 'IAC 572' Jales (V. caribaea $\times 101-14 \mathrm{Mgt})$.

The 3-year-old vines were trained on a unilateral cordon system ( $1 \mathrm{~m}$ above the soil) with vertical shoot positioning by means of iron wires and spaced $2.0 \times 1.1 \mathrm{~m}$ apart. Winter pruning was performed in August 2015 and the grapes were harvested in December 2015, when they reached the technological maturation stage. More details on the grape growing conditions are described by da Silva et al. (2018). Classical techniques were used to determine the $\mathrm{pH}$, soluble solids and titratable acidity in grape samples. Values ranged from 3.18 to 3.29 for $\mathrm{pH}, 14.3$ to $15.5{ }^{\circ} \mathrm{Brix}$ for soluble solids and from 0.66 to $1.14 \%$ tartaric acid for titratable acidity.

\subsection{Grape juice processing}

Grape juices were produced by hot extraction without bagasse pressing. The grapes were manually destemmed and crushed in a manual crusher machine. No enzymatic mixture based on pectinase was added. Grapes were hot-macerated in a water bath at $60 \pm 2{ }^{\circ} \mathrm{C}$ for $1 \mathrm{~h}$, under constant stirring. After maceration the juice was separated by draining and a light pulp crushing. The juice was homogenized, packaged through hot filling of amber glass bottles $(215 \mathrm{~mL}$ capacity) and then subjected to pasteurization at $80^{\circ} \mathrm{C}$ for $3 \mathrm{~min}$. The filled bottles were closed, tumbled, labeled and cooled. The closed bottles were stored under refrigeration $\left(6 \pm 2{ }^{\circ} \mathrm{C}\right)$ for 30 days prior to analysis.

Eight grape juices were produced from combinations of four grape varieties, Isabel Precoce (IP), BRS Carmem (CM), BRS Cora (CR) and IAC 138-22 Máximo (MX), and two rootstocks, 'IAC 766' Campinas (7 66) and 'IAC 572' Jales (5 72 ). They were coded as follows: IP-766, IP-572, CM-766, CM-572, CR-766, CR-572, MX-766 and MX-572. Each juice was prepared in triplicate.

\subsection{Quality analysis - classic parameters and color measurements}

The classic analysis of the grape juices was performed by determining the $\mathrm{pH}$ using a potentiometer $\mathrm{pH}$ analyzer (Tecnal ${ }^{\circledast}$, Piracicaba, SP, Brazil), the soluble solids ( ${ }^{\circ}$ Brix) with a digital refractometer (Reichert ${ }^{\circledR}$, model r2i300, Buffalo, NY, USA), the titratable acidity, expressed as $\mathrm{g}$ of tartaric acid per $100 \mathrm{~mL}^{-1}$ of grape juice, and the soluble solids/titratable acidity (SS/TA) ratio, according to the methodology described by International Organization of Vine and Wine (OIV, 2011).

Color measurements were determined using a Konica Minolta ${ }^{\circledR}$ digital colorimeter, model CR-400 (Konica Minolta Sensing, Inc., Osaka, Japan). The color coordinates of the grape juices were computed according to the CIELAB scale. Color results were expressed as the following parameters: lightness $\left(L^{*}\right)$, ranging from 0 to 100 , i.e., from black to white, respectively; chroma $\left(C^{*}\right)$, which indicates color purity or saturation, the distance from gray (achromatic) toward a pure chromatic color; and hue angle $\left(h^{\circ}\right)$, which indicates sample color $\left(0^{\circ}\right.$, $90^{\circ}, 180^{\circ}$ and $270^{\circ}$ correspond to red, yellow, green and blue, respectively). Color measurements were also determined using the spectrophotometric absorbance of the grape juices at $420,520,620 \mathrm{~nm}$ by UV-Visible spectrophotometry (Instrutherm ${ }^{\circledR}$, São Paulo, SP, Brazil), which were expressed as color intensity $\left(\mathrm{CI}=\mathrm{A}_{420}+\mathrm{A}_{520}+\mathrm{A}_{620}\right)$ and tint $\left(\mathrm{T}=\mathrm{A}_{420} / \mathrm{A}_{520}\right)$, following the methodology described by Glories (1984).

\subsection{Organic acids and sugars determined by HPLC}

Organic acids (tartaric, malic, citric, lactic and acetic acids) and individual sugars (glucose and fructose) were determined using an Agilent HPLC system, model 1260 Infinity LC (Agilent Technologies, Santa Clara, CA, USA) coupled to a diode array detector (DAD, G1315D model) and refractive index detector (RID, G1362A model), according to the methodology described by Coelho et al. (2018). Separation of the compounds was performed on a Hi-Plex $\mathrm{H}$ ion exchange column $(300 \times 7.7 \mathrm{~mm}, 8.0 \mu \mathrm{m}$ internal particles) protected by a PL Hi-Plex $\mathrm{H}$ $(5 \times 3 \mathrm{~mm})$ guard column (Agilent Technologies, Santa Clara, CA, USA). The phase was $0.004 \mathrm{~mol} \mathrm{~L}^{-1} \mathrm{H}_{2} \mathrm{SO}_{4}$ in ultrapure water.

\subsection{Total phenolic compounds and total monomeric anthocyanins}

The total phenolic compounds content of the grape juices was determined by the Folin-Ciocalteu spectrophotometric method (Singleton \& Rossi, 1965). The absorbance value at $765 \mathrm{~nm}$ was compared to a calibration curve and the results were expressed as $\mathrm{mg}$ of gallic acid equivalent (GAE) per liter of grape juice $\left(\mathrm{mg} \mathrm{L}^{-1}\right)$. The total monomeric anthocyanins content was determined using the $\mathrm{pH}$-differential method 
(Lee, Durst, \& Wrolstad, 2005) and expressed as malvidin 3,5-diglucoside equivalents in $\mathrm{mg} \mathrm{L}^{-1}$. Both analysis techniques were performed using an Instrutherm ${ }^{\circledR}$ UV-Vis UV 2000A spectrophotometer.

\subsection{Individual phenolic compounds determined by HPLC}

The determination of the individual phenolic compounds was performed in a Waters liquid chromatograph, model Alliance e2695, equipped with a diode array detector (Waters, Milford, MA, USA) as described by Natividade, Corrêa, de Souza, Pereira, \& Lima (2013). The column used was a Gemini-NX C18 $(150 \mathrm{~mm} \times 4.60 \mathrm{~mm}$, with $3 \mu \mathrm{m}$ internal particles) and the pre-column was a Gemini-NX C18 $(4.0 \mathrm{~mm} \times 3.0 \mathrm{~mm})$, both manufactured by Phenomenex (USA).

\subsection{Antioxidant capacity in vitro}

The in vitro antioxidant capacity was determined using the ABTS radical scavenging method (Kim, Guo, \& Packer, 2002) and DPPH radical scavenging method (Re et al., 1999). For the analysis, the grape juice samples were diluted with ultrapure water until inhibition of the DPPH and ABTS radicals between 20 and $80 \%$ was obtained. The DPPH and ABTS radical solutions at $1 \mathrm{mM}$ were prepared in ethanol and diluted to an absorbance of $0.900 \pm 0.050 \quad(\lambda=734 \mathrm{~nm})$ and $0.700 \pm 0.050(\lambda=517 \mathrm{~nm})$, respectively. The absorbances were determined before and after the addition of grape juice using a UV-Vis 2000A spectrophotometer (Instrutherm ${ }^{\circledR}$, São Paulo, SP, Brazil). In the DPPH method, absorbance was measured at time $t=0$ and $t=30 \mathrm{~min}$ after addition of the sample. In the ABTS method, the absorbance was determined at time $\mathrm{t}=0$ and $\mathrm{t}=6 \mathrm{~min}$ after addition of the sample. For both methods, the analytical standard Trolox was used to construct the calibration curves and the results were expressed as equivalents of Trolox per liter of grape juice (mM TEAC $\mathrm{L}^{-1}$ ).

\subsection{Experimental design and statistical analysis}

Means were subjected to analysis of variance (one-way ANOVA) and compared applying the Tukey test $(p<0.05)$ using the SISVAR, version 5.4, statistical program (Lavras, MG, Brazil). Principal component analysis (PCA) was conducted using XLSTAT statistical software, version 19.4 (Addinsoft, NY, USA), and applied to all analytical data collected for the grape juices. Pearson's correlation analysis was also performed to determine the relation between phenolic compounds and in vitro antioxidant capacity.

\section{Results and discussion}

\subsection{Classic parameters and color measurements}

The 'IAC 572' rootstock provided higher $\mathrm{pH}$ values than 'IAC 766', except for the 'BRS Cora' grape juice (Table 1). In contrast, for the 'BRS Cora' and 'IAC 138-22 Máximo' grape juices the soluble solids content was higher when 'IAC 766' was used. The highest soluble solids values were obtained for the CR-766 and MX-766 juices, with means of 16.3 and $15.7{ }^{\circ}$ Brix, respectively. Nevertheless, all grape juices reached the minimum soluble solids content of $14.0^{\circ}$ Brix, established by Brazilian regulations for whole grape juices (Brasil, 2000).

Despite the high soluble solids content, the grape juices CR-572 and CR-766 maintained high levels of titratable acidity, with 1.45 and

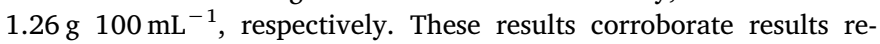
ported by Lima et al. (2014), who found high acid contents $(1.06 \mathrm{~g}$ $100 \mathrm{~mL}^{-1}$ ) in 'BRS Cora' juices produced in the Vale do São Francisco (Northeast, Brazil), even with the high soluble solids content (21.0 ${ }^{\circ}$ Brix), and noted that this grape variety is naturally richer in acids. Because of the high titratable acidity, the CR-572 juice presented the lowest SS/TA ratio (10.7). Low values for this ratio were also found for the juices of CR-766 and IP-766, with averages of 13.0 and 14.3, respectively. These values are below the minimum limit established by Brazilian regulation for whole grape juices, which is 15.0 (Brasil, 2000).

Regarding the color parameters, all grape juices assessed presented lightness $\left(L^{*}\right)$ of around 21.0, which shows that the juices had high color intensity. The IP-766 and IP-572 grape juices presented the highest chroma $\left(C^{*}\right)$ values, with an average of 3.11. High $C^{*}$ values indicate juices with less intense color and vividness. This was evidenced by the negative correlation coefficient between $C^{*}$ and color intensity (CI) $(r=-0.92, p<0.01$; data not shown). In fact, the IP-766 and IP572 juices presented the lowest CI values of the juices studied, with means of 8.25 and 7.02, respectively. In contrast, the highest CI was obtained for the MX-766 juice (27.2), which differed significantly from the others, including the MX-572, with a value of 23.6. These are high values for grape juices, since reported CI values for Brazilian commercial grape juices range from 5.37 to 21.1 (Burin et al., 2010).

\subsection{Organic acids and sugars}

Tartaric and malic acids were the main organic acids detected in every grape juice assessed (Table 2). This is consistent with reports in the literature that tartaric and malic acids can account for more than $80 \%$ of the organic acids found in grapes (Conde et al., 2007; Jackson, 2000).

In the 'Isabel Precoce' juices the tartaric acid content was higher than malic acid content while the opposite scenario was observed for the 'BRS Cora' juices. These organic acids were found in similar proportion in the juices 'BRS Carmem' and 'IAC 138-22 Máximo'. This difference occurs as a function of the grape genetic characteristics and its interaction with climatic conditions during grape ripening (Liu, $\mathrm{Wu}$, Fan, Li, \& Li, 2006).

The citric acid content in the grape juices was on average 10.6 and 10.7 times lower than the content of the tartaric and malic acids, respectively, ranging from 0.13 to $0.48 \mathrm{~g} \mathrm{~L}^{-1}$. This result is similar to those obtained by Coelho et al. (2018) and Lima et al. (2015) for grape juices produced from hybrid grape varieties. Although in a lower concentration, citric acid plays an important role in inhibiting the growth of yeasts in beverages (Silva et al., 2015). In addition, studies have demonstrated the importance of this organic acid in relation to its protective effects on myocardial ischemia/reperfusion injury (Tang et al., 2013).

No lactic acid was found in any of the juices and acetic acid was not detected in the 'Isabel Precoce' and 'BRS Cora' juices. However, a small concentration of acetic acid was detected in the CM-766, MX-766 and MX-572 juices (0.66, 0.64 and $0.54 \mathrm{mg} \mathrm{L}^{-1}$, respectively). These values are slightly above the maximum limit established by Brazilian legislation, which is $0.50 \mathrm{~g} \mathrm{~L}^{-1}$ (Brasil, 2000). In general, this acid is associated with the contamination of grapes or juices by acetic bacteria (Jackson, 2000).

The sum of the glucose and fructose contents in the grape juices ranged from 124 to $151 \mathrm{~g} \mathrm{~L}^{-1}$ (Table 2). These values are in accordance with Brazilian legislation, which establishes a maximum limit of sugars of $200 \mathrm{~g} \mathrm{~L}^{-1}$ (Brasil, 2000). With the exception of 'BRS Carmem' juice, every grape variety had higher glucose and fructose contents when combined with the 'IAC 766' rootstock. This might be related to the different vigor levels of the rootstocks. The vigor conferred by the rootstock to the scion can influence the water and nutrient absorption capacity. In addition, its interaction with the canopy can alter the content of primary metabolites of the vines (Jungmin Lee \& Steenwerth, 2013). The rootstock has also been found to affect the sugar content in 'Concord' grape juices in Southern Brazil, where higher glucose and fructose contents were found using the 'Paulsen 1103' (less vigorous) rootstock in relation to 'VR 043-43' (more vigorous). However, the opposite occurred in juices of the 'Bordô' grape (Barros et al., 2014). 
Table 1

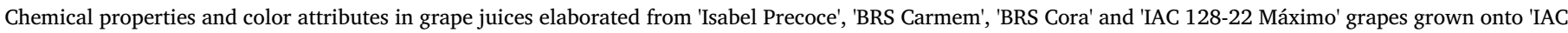
766' and 'IAC 572' rootstocks under tropical conditions in Brazil.

\begin{tabular}{|c|c|c|c|c|c|c|c|c|}
\hline \multirow[t]{2}{*}{ Scion/rootstock combinations } & \multicolumn{2}{|l|}{ Isabel Precoce } & \multicolumn{2}{|l|}{ BRS Carmem } & \multicolumn{2}{|l|}{ BRS Cora } & \multicolumn{2}{|c|}{ IAC 138-22 Máximo } \\
\hline & IAC 766 & IAC 572 & IAC 766 & IAC 572 & IAC 766 & IAC 572 & IAC 766 & IAC 572 \\
\hline \multicolumn{9}{|l|}{ Chemical properties } \\
\hline $\mathrm{pH}$ & $3.21 \pm 0.02^{\mathrm{d}}$ & $3.23 \pm 0.03^{\mathrm{cd}}$ & $3.44 \pm 0.01^{\mathrm{b}}$ & $3.57 \pm 0.01^{\mathrm{a}}$ & $3.13 \pm 0.02^{\mathrm{e}}$ & $3.07 \pm 0.01^{\mathrm{f}}$ & $3.21 \pm 0.02^{\mathrm{d}}$ & $3.27 \pm 0.01^{\mathrm{c}}$ \\
\hline Soluble solids ${ }^{1}$ & $14.9 \pm 0.17^{\text {cde }}$ & $14.4 \pm 0.17^{\mathrm{de}}$ & $15.1 \pm 0.32^{\mathrm{bcd}}$ & $14.9 \pm 0.15^{\text {cde }}$ & $16.3 \pm 0.06^{\mathrm{a}}$ & $15.4 \pm 0.55^{\mathrm{bc}}$ & $15.7 \pm 0.29^{\mathrm{ab}}$ & $14.2 \pm 0.06^{\mathrm{e}}$ \\
\hline Titratable acidity $^{2}$ & $1.05 \pm 0.09^{c}$ & $0.83 \pm 0.00^{\mathrm{d}}$ & $0.88 \pm 0.05^{\mathrm{d}}$ & $0.68 \pm 0.00^{\mathrm{e}}$ & $1.26 \pm 0.03^{\mathrm{b}}$ & $1.45 \pm 0.04^{\mathrm{a}}$ & $0.91 \pm 0.03^{\mathrm{d}}$ & $0.85 \pm 0.03^{\mathrm{d}}$ \\
\hline SS/TA ratio ${ }^{3}$ & $14.3 \pm 1.44^{c}$ & $17.3 \pm 0.17^{\mathrm{b}}$ & $17.1 \pm 1.21^{\mathrm{b}}$ & $21.8 \pm 0.15^{\mathrm{a}}$ & $13.0 \pm 0.28^{c}$ & $10.7 \pm 0.69^{\mathrm{d}}$ & $17.2 \pm 0.80^{\mathrm{b}}$ & $16.7 \pm 0.43^{\mathrm{b}}$ \\
\hline \multicolumn{9}{|l|}{ Color attributes } \\
\hline Lightness & $21.4 \pm 0.07^{\mathrm{a}}$ & $21.4 \pm 0.28^{\mathrm{a}}$ & $20.8 \pm 0.09^{\mathrm{ab}}$ & $20.7 \pm 0.05^{\mathrm{b}}$ & $20.9 \pm 0.14^{\mathrm{ab}}$ & $20.9 \pm 0.05^{\mathrm{ab}}$ & $20.8 \pm 0.30^{\mathrm{ab}}$ & $21.0 \pm 0.37^{\mathrm{ab}}$ \\
\hline Chroma & $3.11 \pm 0.18^{\mathrm{a}}$ & $3.10 \pm 0.32^{\mathrm{a}}$ & $1.73 \pm 0.05^{\mathrm{b}}$ & $1.57 \pm 0.00^{\mathrm{bc}}$ & $1.61 \pm 0.11^{\mathrm{bc}}$ & $1.51 \pm 0.04^{\mathrm{bc}}$ & $1.09 \pm 0.11^{\mathrm{d}}$ & $1.28 \pm 0.00^{\mathrm{cd}}$ \\
\hline Hue angle & $12.0 \pm 0.71^{\mathrm{c}}$ & $12.4 \pm 0.89^{c}$ & $3.09 \pm 1.41^{\mathrm{d}}$ & $1.73 \pm 0.49^{\mathrm{d}}$ & $13.9 \pm 1.72^{\mathrm{c}}$ & $17.3 \pm 1.39^{c}$ & $33.2 \pm 6.29^{\mathrm{a}}$ & $25.4 \pm 1.31^{\mathrm{b}}$ \\
\hline Color intensity & $8.25 \pm 0.37^{d}$ & $7.02 \pm 0.31^{\mathrm{d}}$ & $17.7 \pm 0.85^{c}$ & $16.1 \pm 0.74^{\mathrm{c}}$ & $24.2 \pm 1.02^{\mathrm{b}}$ & $23.5 \pm 0.75^{\mathrm{b}}$ & $27.2 \pm 0.48^{\mathrm{a}}$ & $23.6 \pm 0.48^{b}$ \\
\hline Tint & $0.50 \pm 0.02^{\mathrm{b}}$ & $0.52 \pm 0.03^{\mathrm{b}}$ & $0.65 \pm 0.02^{\mathrm{a}}$ & $0.65 \pm 0.03^{\mathrm{a}}$ & $0.45 \pm 0.01^{\mathrm{c}}$ & $0.43 \pm 0.01^{\mathrm{c}}$ & $0.43 \pm 0.01^{\mathrm{c}}$ & $0.44 \pm 0.01^{\mathrm{c}}$ \\
\hline
\end{tabular}

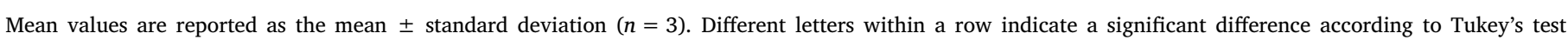
$(p<0.05)$.

1 Soluble solids expressed as ${ }^{\circ}$ Brix.

2 Titratable acidity expressed as $\mathrm{g} 100 \mathrm{~mL}^{-1}$ of tartaric acid.

3 Soluble solids/titratable acidity ratio.

Table 2

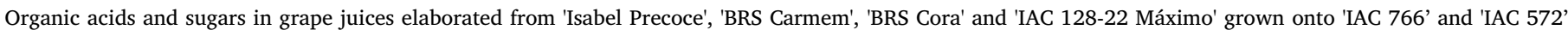
rootstocks under tropical conditions in Brazil.

\begin{tabular}{|c|c|c|c|c|c|c|c|c|}
\hline \multirow[t]{2}{*}{ Scion/rootstock combinations } & \multicolumn{2}{|l|}{ Isabel Precoce } & \multicolumn{2}{|l|}{ BRS Carmem } & \multicolumn{2}{|l|}{ BRS Cora } & \multicolumn{2}{|c|}{ IAC 138-22 Máximo } \\
\hline & IAC 766 & IAC 572 & IAC 766 & IAC 572 & IAC 766 & IAC 572 & IAC 766 & IAC 572 \\
\hline \multicolumn{9}{|l|}{ Organic acids $\left(\mathrm{g} \mathrm{L}^{-1}\right)$} \\
\hline Tartaric & $4.01 \pm 0.15^{\mathrm{a}}$ & $3.96 \pm 0.20^{\mathrm{a}}$ & $3.31 \pm 0.46^{\mathrm{ab}}$ & $2.78 \pm 0.60^{\mathrm{bcd}}$ & $2.59 \pm 0.37^{\mathrm{bcd}}$ & $2.95 \pm 0.06^{\mathrm{bc}}$ & $2.32 \pm 0.20^{\mathrm{cd}}$ & $2.13 \pm 0.06^{\mathrm{d}}$ \\
\hline Malic & $2.66 \pm 0.02^{\mathrm{cd}}$ & $2.47 \pm 0.03^{\mathrm{de}}$ & $3.00 \pm 0.34^{c}$ & $2.39 \pm 0.33^{\mathrm{de}}$ & $4.09 \pm 0.03^{\mathrm{b}}$ & $4.96 \pm 0.01^{\mathrm{a}}$ & $2.44 \pm 0.03^{\mathrm{e}}$ & $2.24 \pm 0.02^{\mathrm{de}}$ \\
\hline Citric & $0.30 \pm 0.00^{\mathrm{c}}$ & $0.24 \pm 0.00^{\mathrm{d}}$ & $0.19 \pm 0.01^{\mathrm{e}}$ & $0.13 \pm 0.03^{\mathrm{f}}$ & $0.44 \pm 0.03^{\mathrm{b}}$ & $0.48 \pm 0.04^{\mathrm{a}}$ & $0.26 \pm 0.01^{\mathrm{cd}}$ & $0.22 \pm 0.00^{\mathrm{de}}$ \\
\hline Acetic & ND & ND & $0.21 \pm 0.00^{\mathrm{c}}$ & $0.66 \pm 0.01^{\mathrm{a}}$ & ND & ND & $0.64 \pm 0.03^{\mathrm{a}}$ & $0.54 \pm 0.00^{\mathrm{b}}$ \\
\hline Lactic & ND & ND & ND & ND & ND & ND & ND & ND \\
\hline$\Sigma$ Organic acids & $6.96 \pm 0.17$ & $6.67 \pm 0.17$ & $6.70 \pm 0.78$ & $5.96 \pm 0.24$ & $7.12 \pm 0.32$ & $8.39 \pm 0.03$ & $5.67 \pm 0.14$ & $5.14 \pm 0.08$ \\
\hline \multicolumn{9}{|l|}{ Sugars $\left(\mathrm{g} \mathrm{L}^{-1}\right)$} \\
\hline Glucose & $73.8 \pm 0.11^{\mathrm{a}}$ & $71.0 \pm 0.26^{\mathrm{bc}}$ & $69.2 \pm 1.00^{\mathrm{cd}}$ & $71.2 \pm 0.23^{\mathrm{b}}$ & $73.8 \pm 0.31^{\mathrm{a}}$ & $69.0 \pm 1.97^{\mathrm{d}}$ & $74.2 \pm 0.21^{\mathrm{a}}$ & $65.1 \pm 0.69^{\mathrm{e}}$ \\
\hline Fructose & $70.2 \pm 0.11^{\mathrm{bc}}$ & $68.0 \pm 0.28^{\mathrm{de}}$ & $66.2 \pm 1.01^{\mathrm{e}}$ & $69.1 \pm 0.16^{\mathrm{cd}}$ & $76.9 \pm 0.33^{\mathrm{a}}$ & $71.7 \pm 1.42^{\mathrm{b}}$ & $66.6 \pm 0.15^{\mathrm{e}}$ & $59.2 \pm 0.37^{f}$ \\
\hline$\Sigma$ Sugars & $144 \pm 0.00$ & $139 \pm 0.46$ & $135 \pm 2.01$ & $140 \pm 0.33$ & $151 \pm 0.64$ & $141 \pm 2.81$ & $141 \pm 0.35$ & $124 \pm 0.85$ \\
\hline
\end{tabular}

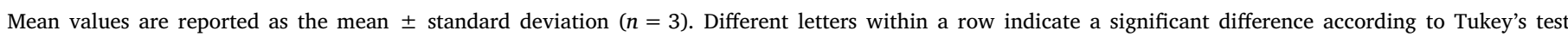
$(p<0.05)$.

ND - not detected.

\subsection{Anthocyanins profile}

Anthocyanins were the phenolic compounds present in highest proportion in the grape juices, ranging from 76.6 to $94.0 \%$ of the total phenolic content quantified by HPLC (Table 3 ).

Juices MX-766 and MX-572 presented the highest content of anthocyanins, with 661 and $582 \mathrm{mg} \mathrm{L}^{-1}$, respectively. Of these, more than $50 \%$ corresponded only to malvidin 3,5-diglucoside (359 and $346 \mathrm{mg} \mathrm{L}^{-1}$, respectively). No reports of the levels of individual anthocyanins in 'IAC 138-22 Máximo' grape juice could be found in the literature. However, the contents observed in this study are higher compared with grape juices obtained from other Vitis labrusca and hybrids varieties (de Sá Borges et al., 2013; Lima et al., 2015; Silva et al., 2016). This includes the anthocyanin content $\left(464-669 \mathrm{mg} \mathrm{L}^{-1}\right)$ reported for BRS Violeta grape juice produced in Vale do São Francisco (Lima et al., 2014; Natividade et al., 2013). The 'BRS Violeta' ('BRS Rúbea' x 'IAC 1398-21') has been considered by Brazilian researchers a very interesting grape for the elaboration of red wines and grape juices due to the high color intensity, which improves the product, and high antioxidant capacity (Rebello et al., 2013). Thus, the 'IAC 138-22 Máximo' is noteworthy as an additional option for Brazilian winegrowers, with great potential to improve the color of grape juices and red wines from other varieties.
The contents of malvidin 3-glucoside, delphinidin 3-glucoside, peonidin 3-glucoside, pelargonidin 3-glucoside and petunidin 3-glucoside in MX-766 juice was significantly higher than in MX-572 juice. This shows a strong influence of the rootstock on the 'IAC 138-22 Máximo' grape, with greater affinity observed for 'IAC 766'. It is still not well understood how the rootstock affects the biosynthesis and the content of these compounds. Previous studies on 'Cabernet Sauvignon' (V. vinifera) show that this effect is linked to the expression of genes related to flavonoid biosynthesis (VviPAL3-like, VviCHS3, VviLAR2 and VviUFGT) (Corso et al., 2016).

'Isabel Precoce' grape juices provided the lowest content of anthocyanins. Nevertheless, the anthocyanins content found for the IP-766 and IP-572 grape juices in this study were higher than those observed by Nassur et al. (2014) and Lima et al. (2014) in grape juices from the same variety. Although Isabel Precoce is a Vitis labrusca cultivar, the main anthocyanin detected in the juices was malvidin 3-glucoside, which is consistent with other studies in the literature (Natividade et al., 2013; Silva et al., 2016).

The grape juices from 'Isabel Precoce' presented a total monomeric anthocyanins (TMA) content around 5.6 times lower than 'IAC 138-22 Máximo' juices, with averages of 174 and $981 \mathrm{mg} \mathrm{L}^{-1}$, respectively. In both 'Isabel Precoce' and 'IAC 138-22 Máximo' juices no effect of the rootstocks was detected. Similar results were obtained for 'Concord' 
Table 3

Phenolic compounds in grape juices elaborated from 'Isabel Precoce', 'BRS Carmem', 'BRS Cora' and 'IAC 128-22 Máximo' grown onto 'IAC 766' and 'IAC 572' rootstocks under tropical conditions in Brazil.

\begin{tabular}{|c|c|c|c|c|c|c|c|c|}
\hline \multirow[t]{2}{*}{ Scion/rootstock combinations } & \multicolumn{2}{|l|}{ Isabel Precoce } & \multicolumn{2}{|l|}{ BRS Carmem } & \multicolumn{2}{|l|}{ BRS Cora } & \multicolumn{2}{|c|}{ IAC 138-22 Máximo } \\
\hline & IAC 766 & IAC 572 & IAC 766 & IAC 572 & IAC 766 & IAC 572 & IAC 766 & IAC 572 \\
\hline \multicolumn{9}{|l|}{ Anthocyanins ${ }^{1}$} \\
\hline Malvidin 3,5-diglc & $14.8 \pm 0.49^{c}$ & $14.5 \pm 0.38^{c}$ & $167 \pm 7.06^{\mathrm{b}}$ & $175 \pm 10.4^{\mathrm{b}}$ & $4.27 \pm 1.50^{c}$ & $1.25 \pm 0.26^{\mathrm{c}}$ & $359 \pm 18.8^{\mathrm{a}}$ & $346 \pm 3.01^{\mathrm{a}}$ \\
\hline Malvidin 3-glc & $52.2 \pm 2.27^{\mathrm{c}}$ & $44.6 \pm 4.14^{c}$ & $3.70 \pm 0.62^{\mathrm{d}}$ & $2.37 \pm 0.32^{\mathrm{d}}$ & $1.80 \pm 0.60^{\mathrm{d}}$ & $2.13 \pm 0.32^{\mathrm{d}}$ & $132 \pm 9.55^{\mathrm{a}}$ & $101 \pm 0.60^{\mathrm{b}}$ \\
\hline Cyanidin 3,5-diglc & ND & ND & ND & ND & $28.5 \pm 1.02^{\mathrm{a}}$ & $25.1 \pm 0.45^{\mathrm{b}}$ & $2.93 \pm 0.35^{c}$ & $2.83 \pm 0.23^{\mathrm{c}}$ \\
\hline Cyanidin 3-glc & $4.43 \pm 0.21^{\mathrm{d}}$ & $3.03 \pm 0.64^{d}$ & $14.5 \pm 0.67^{\mathrm{b}}$ & $13.9 \pm 0.82^{\mathrm{b}}$ & $11.2 \pm 0.65^{\mathrm{c}}$ & $10.6 \pm 0.21^{\mathrm{c}}$ & $26.8 \pm 1.35^{\mathrm{a}}$ & $25.1 \pm 0.15^{\mathrm{a}}$ \\
\hline Delphinidin 3-glc & $5.37 \pm 0.35^{\mathrm{d}}$ & $3.17 \pm 1.19^{\mathrm{d}}$ & $3.47 \pm 0.57^{\mathrm{d}}$ & $2.87 \pm 0.21^{\mathrm{d}}$ & $75.9 \pm 4.94^{\mathrm{a}}$ & $77.2 \pm 1.42^{\mathrm{a}}$ & $51.9 \pm 3.37^{\mathrm{b}}$ & $37.2 \pm 0.23^{c}$ \\
\hline Peonidin 3-glc & $11.7 \pm 0.55^{\mathrm{a}}$ & $9.70 \pm 0.70^{\mathrm{b}}$ & $0.97 \pm 0.21^{\mathrm{e}}$ & $0.83 \pm 0.06^{\mathrm{e}}$ & $1.23 \pm 0.06^{\mathrm{e}}$ & $1.43 \pm 0.06^{\mathrm{e}}$ & $5.87 \pm 0.40^{c}$ & $4.67 \pm 0.06^{\mathrm{d}}$ \\
\hline Pelargonidin 3-glc & $8.20 \pm 0.50^{\mathrm{d}}$ & $5.33 \pm 1.86^{\mathrm{de}}$ & $1.26 \pm 0.36^{\mathrm{e}}$ & $0.69 \pm 0.03^{\mathrm{e}}$ & $23.3 \pm 0.26^{\mathrm{c}}$ & $21.4 \pm 0.53^{\mathrm{c}}$ & $52.9 \pm 4.42^{\mathrm{a}}$ & $38.4 \pm 0.32^{\mathrm{b}}$ \\
\hline Petunidin 3-glc & $0.40 \pm 0.00^{\mathrm{e}}$ & $0.25 \pm 0.05^{\mathrm{e}}$ & $13.4 \pm 0.65^{c}$ & $14.6 \pm 0.89^{c}$ & $8.60 \pm 0.36^{\mathrm{d}}$ & $8.47 \pm 0.23^{\mathrm{d}}$ & $28.8 \pm 1.57^{\mathrm{a}}$ & $26.2 \pm 0.15^{\mathrm{b}}$ \\
\hline$\Sigma$ Anthocyanins & $97.1 \pm 16.9$ & $80.5 \pm 14.8$ & $204 \pm 57.5$ & $210 \pm 60.4$ & $155 \pm 25.9$ & $148 \pm 25.4$ & $661 \pm 118$ & $582 \pm 114$ \\
\hline$\%$ of total composition & 76.60 & 77.28 & 90.42 & 90.58 & 83.13 & 81.58 & 94.03 & 93.13 \\
\hline \multicolumn{9}{|l|}{ Flavonols $^{1}$} \\
\hline Kaempferol & $1.07 \pm 0.15^{\mathrm{ab}}$ & $0.90 \pm 0.10^{\mathrm{bc}}$ & $0.73 \pm 0.15^{\mathrm{bc}}$ & $0.60 \pm 0.10^{c}$ & $0.10 \pm 0.00^{\mathrm{d}}$ & $0.13 \pm 0.06^{\mathrm{d}}$ & $1.33 \pm 0.31^{\mathrm{a}}$ & $0.50 \pm 0.10^{\mathrm{cd}}$ \\
\hline Myricetin & $0.10 \pm 0.00^{\mathrm{c}}$ & $0.10 \pm 0.00^{c}$ & $0.10 \pm 0.00^{c}$ & $0.10 \pm 0.00^{c}$ & $0.10 \pm 0.00^{c}$ & $0.10 \pm 0.00^{c}$ & $0.63 \pm 0.06^{\mathrm{b}}$ & $0.70 \pm 0.00^{\mathrm{a}}$ \\
\hline Isorhamnetin & $0.27 \pm 0.06^{\mathrm{b}}$ & $0.23 \pm 0.06^{\mathrm{b}}$ & $2.40 \pm 0.44^{\mathrm{a}}$ & $2.17 \pm 0.42^{\mathrm{a}}$ & ND & ND & ND & ND \\
\hline Rutin & $0.20 \pm 0.00^{\mathrm{e}}$ & $0.17 \pm 0.06^{\mathrm{e}}$ & $0.80 \pm 0.10^{\mathrm{d}}$ & $0.83 \pm 0.12^{\mathrm{d}}$ & $1.03 \pm 0.15^{\mathrm{cd}}$ & $1.23 \pm 0.15^{\mathrm{c}}$ & $3.50 \pm 0.20^{\mathrm{b}}$ & $3.87 \pm 0.06^{\mathrm{a}}$ \\
\hline Quercetin & ND & ND & ND & ND & ND & ND & $0.10 \pm 0.00^{\mathrm{a}}$ & $0.10 \pm 0.00^{\mathrm{a}}$ \\
\hline Isoquercetin & $6.53 \pm 1.07^{c}$ & $5.97 \pm 0.50^{\mathrm{cd}}$ & $3.37 \pm 0.75^{\mathrm{e}}$ & $3.57 \pm 0.95^{\mathrm{de}}$ & $7.33 \pm 0.49^{\mathrm{bc}}$ & $9.67 \pm 0.87^{\mathrm{b}}$ & $13.2 \pm 1.34^{\mathrm{a}}$ & $15.3 \pm 0.36^{\mathrm{a}}$ \\
\hline$\Sigma$ Flavonols & $8.17 \pm 2.77$ & $7.37 \pm 2.53$ & $7.40 \pm 1.35$ & $7.27 \pm 1.41$ & $8.57 \pm 3.49$ & $11.1 \pm 4.62$ & $18.7 \pm 5.42$ & $20.5 \pm 6.44$ \\
\hline$\%$ of total composition & 6.44 & 7.07 & 3.27 & 3.13 & 4.60 & 6.15 & 2.67 & 3.28 \\
\hline \multicolumn{9}{|l|}{ Stilbene $^{1}$} \\
\hline trans-resveratrol & $0.30 \pm 0.00^{\mathrm{ef}}$ & $0.23 \pm 0.06^{\mathrm{f}}$ & $0.53 \pm 0.12^{\mathrm{cd}}$ & $0.43 \pm 0.06^{\mathrm{de}}$ & $0.70 \pm 0.00^{c}$ & $0.70 \pm 0.00^{\mathrm{c}}$ & $2.37 \pm 0.12^{\mathrm{a}}$ & $1.87 \pm 0.06^{\mathrm{b}}$ \\
\hline$\%$ of total composition & 0.24 & 0.22 & 0.24 & 0.19 & 0.38 & 0.39 & 0.34 & 0.30 \\
\hline \multicolumn{9}{|l|}{ Phenolic acids ${ }^{1}$} \\
\hline Gallic acid & $5.97 \pm 0.21^{\mathrm{a}}$ & $4.30 \pm 0.26^{\mathrm{b}}$ & $4.47 \pm 0.57^{\mathrm{b}}$ & $4.60 \pm 0.10^{\mathrm{b}}$ & $6.13 \pm 0.23^{\mathrm{a}}$ & $6.03 \pm 0.12^{\mathrm{a}}$ & $4.83 \pm 0.31^{\mathrm{b}}$ & $4.27 \pm 0.06^{\mathrm{b}}$ \\
\hline Caffeic acid & $10.2 \pm 0.53^{\mathrm{a}}$ & $8.03 \pm 0.25^{\mathrm{b}}$ & $1.53 \pm 0.15^{\mathrm{e}}$ & $1.70 \pm 0.10^{\mathrm{e}}$ & $5.87 \pm 0.25^{\mathrm{c}}$ & $4.73 \pm 0.06^{\mathrm{d}}$ & $5.03 \pm 0.25^{\mathrm{d}}$ & $4.83 \pm 0.15^{\mathrm{d}}$ \\
\hline Cinnamic acid & $0.23 \pm 0.06^{\mathrm{e}}$ & $0.20 \pm 0.00^{\mathrm{e}}$ & $0.80 \pm 0.00^{\mathrm{d}}$ & $0.80 \pm 0.00^{\mathrm{d}}$ & $4.30 \pm 0.10^{\mathrm{a}}$ & $4.00 \pm 0.10^{\mathrm{b}}$ & $1.87 \pm 0.15^{\mathrm{c}}$ & $1.80 \pm 0.10^{\mathrm{c}}$ \\
\hline Chlorogenic acid & $1.53 \pm 0.15^{\mathrm{a}}$ & $1.60 \pm 0.36^{\mathrm{a}}$ & $0.47 \pm 0.06^{\mathrm{b}}$ & $0.43 \pm 0.06^{\mathrm{b}}$ & $0.43 \pm 0.06^{\mathrm{b}}$ & $0.43 \pm 0.06^{\mathrm{b}}$ & $0.60 \pm 0.17^{\mathrm{b}}$ & $0.40 \pm 0.00^{\mathrm{b}}$ \\
\hline$\rho$-Coumaric acid & $0.20 \pm 0.00^{c}$ & $0.20 \pm 0.00^{\mathrm{c}}$ & $1.73 \pm 0.15^{\mathrm{b}}$ & $1.87 \pm 0.21^{\mathrm{b}}$ & $2.00 \pm 0.10^{\mathrm{b}}$ & $2.10 \pm 0.10^{\mathrm{b}}$ & $4.00 \pm 0.17^{\mathrm{a}}$ & $3.97 \pm 0.15^{\mathrm{a}}$ \\
\hline$\Sigma$ Phenolic acids & $18.1 \pm 4.37$ & $14.3 \pm 3.34$ & $9.00 \pm 1.58$ & $9.40 \pm 1.63$ & $18.7 \pm 2.48$ & $17.3 \pm 2.21$ & $16.3 \pm 1.95$ & $15.3 \pm 1.88$ \\
\hline$\%$ of total composition & 14.30 & 13.76 & 3.98 & 4.05 & 10.06 & 9.56 & 2.33 & 2.45 \\
\hline \multicolumn{9}{|l|}{ Flavanols $^{1}$} \\
\hline (-)-Epic. gallate & $2.17 \pm 0.32^{\mathrm{abc}}$ & $1.27 \pm 0.32^{\mathrm{d}}$ & $2.33 \pm 0.40^{\mathrm{ab}}$ & $2.17 \pm 0.35^{\mathrm{abc}}$ & $2.37 \pm 0.38^{\mathrm{ab}}$ & $2.77 \pm 0.12^{\mathrm{a}}$ & $1.50 \pm 0.10^{\mathrm{cd}}$ & $1.80 \pm 0.10^{\mathrm{bcd}}$ \\
\hline (-)-Epig. gallate & $0.90 \pm 0.10^{\mathrm{cd}}$ & $0.47 \pm 0.06^{\mathrm{d}}$ & $2.40 \pm 0.20^{\mathrm{b}}$ & $2.60 \pm 0.20^{\mathrm{b}}$ & $1.03 \pm 0.21^{\mathrm{cd}}$ & $1.43 \pm 0.25^{\mathrm{c}}$ & $2.97 \pm 0.50^{\mathrm{ab}}$ & $3.47 \pm 0.35^{\mathrm{a}}$ \\
\hline$\Sigma$ Flavanols & $3.07 \pm 0.90$ & $1.73 \pm 0.57$ & $4.73 \pm 0.05$ & $4.77 \pm 0.31$ & $3.40 \pm 0.94$ & $4.20 \pm 0.94$ & $4.47 \pm 1.04$ & $5.27 \pm 1.18$ \\
\hline$\%$ of total composition & 2.42 & 1.66 & 2.09 & 2.05 & 1.83 & 2.32 & 0.64 & 0.84 \\
\hline TMA $^{2}$ & $186 \pm 9.1^{\mathrm{e}}$ & $162 \pm 21.3^{\mathrm{e}}$ & $836 \pm 23.1^{c}$ & $890 \pm 14.1^{b}$ & $831 \pm 10.9^{c}$ & $765 \pm 11.2^{\mathrm{d}}$ & $995 \pm 9.3^{\mathrm{a}}$ & $966 \pm 1.9^{\mathrm{a}}$ \\
\hline $\mathrm{TPC}^{3}$ & $1004 \pm 16.3^{\mathrm{d}}$ & $913.9 \pm 39.7^{\mathrm{d}}$ & $2008 \pm 56.1^{\mathrm{c}}$ & $2039 \pm 41.9^{\mathrm{bc}}$ & $2128 \pm 23.4^{\mathrm{b}}$ & $2141 \pm 38.7^{b}$ & $3485 \pm 23.4^{\mathrm{a}}$ & $3469 \pm 52.8^{\mathrm{a}}$ \\
\hline
\end{tabular}

Mean values are reported as the mean \pm standard deviation $(n=3)$. Different letters within a row indicate a significant difference according to Tukey's test $(p<0.05)$.

Nomenclature of abbreviations: glc, glucoside; diglc, diglucoside; Epic, (-)-Epicatechin gallate; Epig, (-)-Epigallocatechin gallate; ND, not detected; $\Sigma$, total compounds quantified by HPLC in each phenolic class.

1 Expressed as $\mathrm{mg} \mathrm{L}^{-1}$.

${ }^{2}$ TMA, total monomeric anthocyanins quantified by the technique of difference in $\mathrm{pH}$ and expressed as equivalent to malvidin 3,5-diglucoside.

3 TPC, total phenolic compounds measured with Folin-Ciocalteau reagent and expressed as $\mathrm{mg} \mathrm{L}^{-1}$ equivalent to gallic acid.

grape juices combined with 'IAC 766' and 'IAC 572' rootstocks in southern Brazil (de Sá Borges et al., 2013). In contrast, CM-572 juice presented higher TMA content than CM-766 juice, while a higher content of these pigments was found in the CR-766 juice compared to CR-572 juice. Nassur et al. (2014) found for the grape juice produced from the 'BRS Cora'/'IAC 572' combination a content of anthocyanins greater than that of the 'BRS Cora'/'IAC 766' juice. These results suggest that the content of anthocyanins in grape juice is not only dependent on the isolated effect of the rootstock on the scion but is also influenced by the scion-rootstock genetic interaction.

The grape juices of 'BRS Carmem', 'BRS Cora' and 'IAC 138-22 Máximo' presented higher TMA content than those reported in the literature for Brazilian juices produced from Vitis labrusca and hybrid grapes, for which values ranging from 15.4 to $617 \mathrm{mg} \mathrm{L}^{-1}$ have been reported (de Sá Borges et al., 2013; Lima et al., 2014; Nassur et al., 2014; Padilha et al., 2017; Silva et al., 2016). The TMA content in the same grape juices was also higher compared to commercial grape juices produced in Spain (129-535 $\mathrm{mg} \mathrm{L}^{-1}$ ) (Moreno-Montoro, Olalla-herrera,
Gimenez-Martinez, Navarro-alarcon, \& Rufián-Henares, 2015).

\subsection{Flavonols and trans-resveratrol}

Grape juices MX-766 and MX-572 presented the highest content of flavonols, with a mean of $19.6 \mathrm{mg} \mathrm{L}^{-1}$, of which $72 \%\left(14.3 \mathrm{mg} \mathrm{L}^{-1}\right)$ corresponded to isoquercetin (Table 3 ). This compound was also predominant in 'BRS Cora', 'Isabel Precoce' and 'BRS Carmem' juices, although at lower concentrations, with averages of 8.50, 6.25 and $3.47 \mathrm{mg} \mathrm{L}^{-1}$, respectively. The total content of flavonols determined by HPLC in this study was superior to values previously published by Lima et al. (2014, 2015) and Natividade et al. (2013). However, these authors did not determine the isoquercetin content.

The MX-766 juice presented the highest $t$-resveratrol content, which differed significantly from that of the other juices, including the MX572 (2.37 and $1.87 \mathrm{mg} \mathrm{L}^{-1}$, respectively). These values are higher than those reported in the literature for grape juices from 'Isabel Precoce', 'BRS Cora', 'BRS Violeta' and 'Bordô', in which contents ranging from 


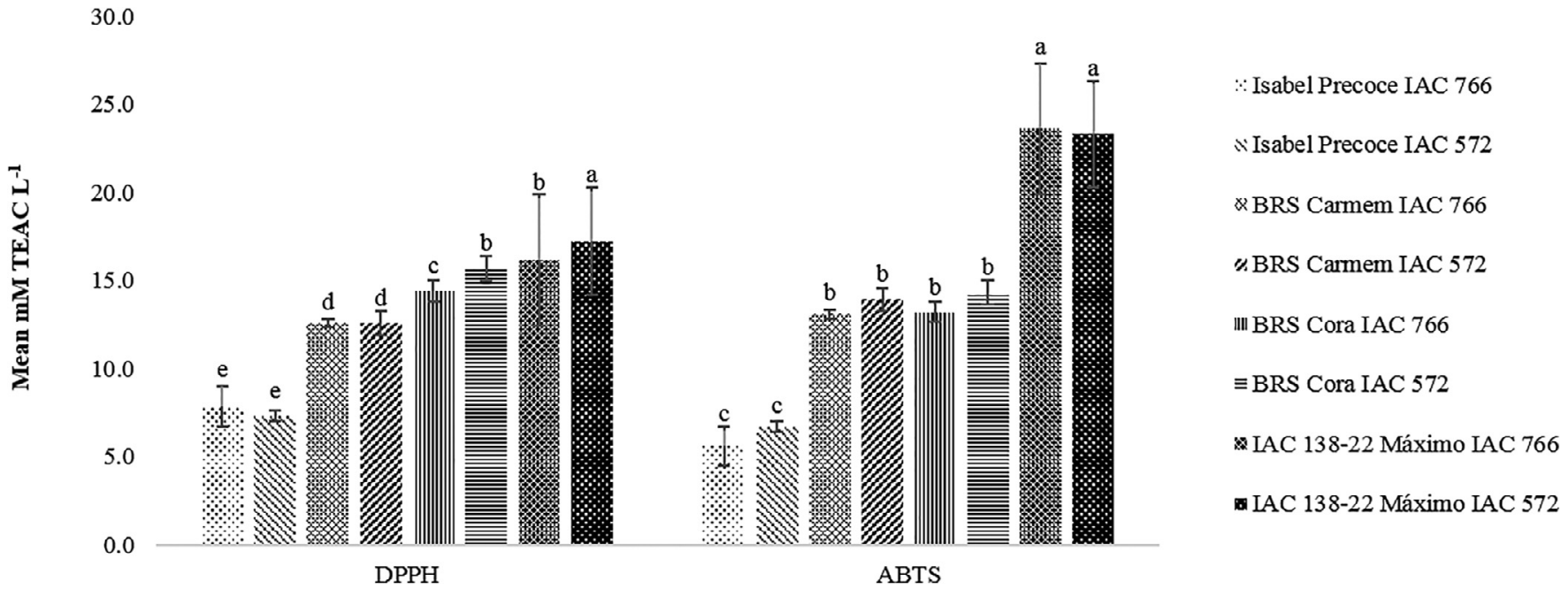

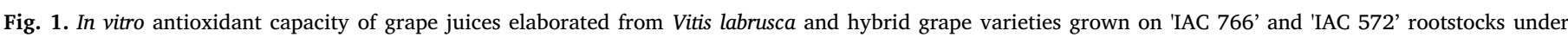

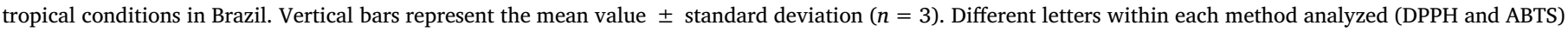
indicate a significant difference according to Tukey's test $(p<0.05)$.

0.00 to $1.10 \mathrm{mg} \mathrm{L}^{-1}$ were detected (Dani et al., 2007; Lima et al., 2014; Natividade et al., 2013; Silva et al., 2016).

On average, grape juices from 'BRS Cora', 'BRS Carmem' and 'Isabel Precoce' had trans-resveratrol contents of $0.70,0.48$ and $0.27 \mathrm{mg} \mathrm{L}^{-1}$, respectively (Table 3 ). The $t$-resveratrol is currently one of the most studied phenolics and has been associated with several beneficial effects on human health with properties including bactericidal, fungicidal and anticancer activity as well as cardioprotective action (Ali, Maltese, Choi, \& Verpote, 2010). Grape juices with high levels of this compound, such as those investigated in this study, might be a good source of resveratrol for the consumer, especially for abstainers.

\subsection{Phenolic acids and flavanols}

The content of phenolic acids corresponded to $2.33-14.3 \%$ of the total phenolic compounds (Table 3). Gallic and caffeic acids were the main phenolic acids found in all of the grape juices analyzed. In general, the content of phenolic acids observed in this study was below the average found for Brazilian commercial grape juices, in which the average contents of gallic, caffeic, chlorogenic and $\rho$-coumaric acids is 9.56, 5.81, 27.9 and $7.24 \mathrm{mg} \mathrm{L}^{-1}$, respectively (Margraf, Santos, Andrade, Van Ruth, \& Granato, 2016). In contrast, the contents of gallic, caffeic and $\rho$-coumaric acids in the juices obtained in this study are higher than those found in commercial juices from Spain, that is, 2.00, 0.65 and $0.62 \mathrm{mg} \mathrm{L}^{-1}$, respectively (Moreno-Montoro et al., 2015).

Regarding the total amount of flavanols in the grape juices, the highest (-)-epigallocatechin gallate content was detected for MX-572 and MX-766 juices, with an average of $3.22 \mathrm{mg} \mathrm{L}^{-1}$. The (-)-epicatechin gallate was present in similar concentrations in all juices analyzed, with an average of $2.05 \mathrm{mg} \mathrm{L}^{-1}$ (Table 3). This value is similar to those reported for grape juices from V. labrusca and hybrid grape varieties (Lima et al., 2015; Silva et al., 2016).

\subsection{Total phenolic compounds}

The total phenolics compounds (TPC) concentration measured by spectrophotometry differed significantly $(p<0.05)$ among the grape juices analyzed (Table 3). Grape juices MX-766 and MX-572 presented the highest phenolic content, with an average of $3477 \mathrm{mg} \mathrm{L}^{-1}$. The TPC contents for 'BRS Cora' and 'BRS Carmem' juices were similar (average of $2079 \mathrm{mg} \mathrm{L}^{-1}$ ). These values exceed the TPC content in 'Isabel Precoce' grape juices $\left(959 \mathrm{mg} \mathrm{L}^{-1}\right.$ ), as expected. The new hybrid grape varieties evaluated in this study were developed to have high anthocyanin content, which is the major technical deficiency associated with 'Isabel' grapes, the main Brazilian grape used in juice production.

The TPC content in 'BRS Cora' and 'BRS Carmem' grape juices is similar to values reported for other grape juices from hybrid varieties produced in different regions in Brazil, which range from 779 to $2647 \mathrm{mg} \mathrm{L}^{-1}$ (de Sá Borges et al., 2013; Lima et al., 2015, 2014; Padilha et al., 2017; Silva et al., 2016). However, the phenolic content detected in 'IAC 138-22 Máximo' grape juice is above the maximum value reported by the cited authors, indicating that this juice is a potential source of phenolic compounds for the consumer. The importance of the phenolic composition in grape juice is mainly related to its contribution to the sensory quality of the juice in relation to the color and flavor, as well as its antioxidant capacity (Granato et al., 2016).

Regarding the rootstocks, no effect of 'IAC 766' or 'IAC 572' on total phenolic compounds in the grape juices was detected in this study. In a previous study, the same rootstocks did not influence the phenolic content in Concord grape juice elaborated in the southern region of Brazil (de Sá Borges et al., 2013).

\subsection{Antioxidant capacity in vitro}

The in vitro antioxidant capacity of the grape juices was determined using the DPPH and ABTS radical scavenging methods. Significant differences $(p<0.05)$ between the grape juices were detected using both methods (Fig. 1). The antioxidant capacity ranged between 7.33 and 17.2 mM TEAC L $^{-1}$ when measured by the DPPH method and 5.59 to $23.6 \mathrm{mMTEACL}^{-1}$ according to the ABTS method. For both methods, the highest and lowest values were found in the grape juices 'IAC 138-22 Máximo' and 'Isabel Precoce', respectively.

Based on the ABTS results for all grape juices analyzed, the rootstocks had no effect on the antioxidant capacity. Similarly, the results obtained with the DPPH method showed no influence of the 'IAC 766' and 'IAC 572' rootstocks on the antioxidant capacity of 'Isabel Precoce' and 'BRS Carmem' grape juices. Similar results were obtained for 'Concord' grape juices, also considering the 'IAC 766' and 'IAC 572' rootstocks, with AOX values of 11.9 and 10.9 mM TEAC L $^{-1}$, respectively, being reported (de Sá Borges et al., 2013). However, on applying the DPPH method, the MX-572 juice presented a higher AOX value (17.2 mM TEAC L $^{-1}$ ) than the MX-766 juice (16.2 mM TEAC $\left.^{-1}\right)$. Similarly, the combination with the 'IAC 572' rootstock provided a higher AOX value in the case of 'BRS Cora' juices, with mean values of 15.7 and 14.4 mM TEAC L $^{-1}$ for CR-572 and CR-766 juices, respectively. Thus, 
Table 4

Pearson's correlation analysis between phenolic compounds in grape juice and in vitro antioxidant activities measured by the DPPH and ABTS methods.

\begin{tabular}{|c|c|c|c|c|}
\hline \multirow[t]{2}{*}{ Phenolics compounds } & \multicolumn{2}{|l|}{$\mathrm{DPPH}$} & \multicolumn{2}{|l|}{ ABTS } \\
\hline & Pearson $r$ & $p$ Value & Pearson $r$ & $p$ Value \\
\hline \multicolumn{5}{|l|}{ Anthocyanins } \\
\hline Malvidin 3,5-diglc & 0.591 & 0.123 & $0.861^{\mathrm{a}}$ & 0.006 \\
\hline Malvidin 3-glc & 0.256 & 0.501 & 0.585 & 0.128 \\
\hline Cyanidin 3,5-diglc & 0.416 & 0.306 & 0.049 & 0.907 \\
\hline Cyanidin 3-glc & $0.832^{\mathrm{a}}$ & 0.009 & $0.978^{\mathrm{a}}$ & $<0.001$ \\
\hline Delphinidin 3-glc & 0.694 & 0.056 & 0.449 & 0.264 \\
\hline Peonidin 3-glc & -0.646 & 0.083 & -0.402 & 0.325 \\
\hline Pelargonidin 3-glc & $0.713^{\mathrm{b}}$ & 0.047 & $0.816^{\mathrm{b}}$ & 0.014 \\
\hline Petunidin 3-glc & $0.813^{\mathrm{b}}$ & 0.014 & $0.973^{\mathrm{a}}$ & $<0.001$ \\
\hline \multicolumn{5}{|l|}{ Flavonols } \\
\hline Kaempferol & -0.376 & 0.354 & 0.001 & 0.994 \\
\hline Myricetin & 0.623 & 0.099 & $0.862^{\mathrm{a}}$ & 0.006 \\
\hline Isorhamnetin & -0.169 & 0.689 & -0.157 & 0.711 \\
\hline Rutin & $0.804^{\mathrm{b}}$ & 0.017 & $0.956^{\mathrm{a}}$ & $<0.001$ \\
\hline Quercetin & 0.619 & 0.102 & $0.865^{\mathrm{a}}$ & 0.006 \\
\hline Isoquercetin & 0.658 & 0.076 & $0.754^{\mathrm{b}}$ & 0.031 \\
\hline \multicolumn{5}{|l|}{ Stilbene } \\
\hline trans-resveratrol & $0.742^{\mathrm{b}}$ & 0.035 & $0.924^{\mathrm{a}}$ & 0.001 \\
\hline \multicolumn{5}{|l|}{ Phenolic acids } \\
\hline Gallic acid & 0.007 & 0.989 & -0.305 & 0.960 \\
\hline Caffeic acid & -0.545 & 0.163 & -0.482 & 0.226 \\
\hline Cinnamic acid & 0.662 & 0.734 & 0.342 & 0.406 \\
\hline Chlorogenic acid & $-0.886^{\mathrm{a}}$ & 0.003 & $-0.716^{\mathrm{b}}$ & 0.046 \\
\hline$\rho$-Coumaric acid & $0.927^{\mathrm{a}}$ & 0.001 & $0.997^{\mathrm{a}}$ & $<0.001$ \\
\hline \multicolumn{5}{|l|}{ Flavanols } \\
\hline (-)-Epicatechin gallate & 0.255 & 0.545 & -0.139 & 0.740 \\
\hline (-)-Epigallocatechin gallate & $0.716^{\mathrm{b}}$ & 0.046 & $0.867^{\mathrm{a}}$ & 0.005 \\
\hline Total monomeric anthocyanins & $0.917^{\mathrm{a}}$ & 0.001 & $0.862^{\mathrm{a}}$ & 0.006 \\
\hline Total phenolics compounds & $0.918^{\mathrm{a}}$ & 0.001 & $0.996^{\mathrm{a}}$ & $<0.001$ \\
\hline $\mathrm{DPPH}$ & - & & $0.904^{\mathrm{a}}$ & 0.002 \\
\hline
\end{tabular}

a Significant correlations at $1 \%$ probability of error $(p<0.01)$.

b Significant correlations at $5 \%$ probability of error $(p<0.05)$.

the results indicate that the scion-rootstock interaction can have a greater influence on grape juice antioxidant capacity than the isolated effect of the rootstock.

The AOX values for the 'BRS Cora' and 'BRS Carmem' juices were similar to those of commercial grape juices elaborated from new hybrid grape varieties in Vale do São Francisco, Brazil. For these commercial juices the AOX ranges were 10.0-14.4 and 12.5-18.1 $\mathrm{mM} \mathrm{TEAC} \mathrm{L}^{-1}$, measured by the DPPH and ABTS methods, respectively (Padilha et al., 2017). However, the 'IAC 138-22 Máximo' juices presented AOX values similar to those reported for commercial grape juices produced in Spain, with values of 15.1 to $27.1 \mathrm{mMTEAC}^{-1}$ (Moreno-Montoro et al., 2015).

\subsection{Pearson's correlation analysis}

Pearson's correlation analysis was performed to investigate the contribution of the phenolic compounds to the in vitro antioxidant capacity (DPPH and ABTS) of grape juices (Table 4). For discussion purposes the positive correlation coefficients $(r)$ were considered, with significance set at $1 \%$ probability of error $(p<0.01)$. The number of compounds that met these conditions was higher when the ABTS method was used.

On applying the DPPH method, significant correlations $(p<0.01)$ were detected only for cyanidin 3-glucoside $(r=0.83)$ and $\rho$-coumaric acid $(r=0.93)$. However, on applying the ABTS method, significant correlations were detected for malvidin 3,5-diglucoside $(r=0.86)$, cyanidin 3-glucoside $(\mathrm{r}=0.98)$, petunidin 3-glucoside $(r=0.97)$, myricetin $(r=0.86)$, rutin $(r=0.96)$, quercetin $(r=0.87)$, $\rho$-coumaric acid $(r=0.99)$ and (-)-epigallocatechin gallate $(r=0.87)$.
The correlation coefficients for the relation between the antioxidant capacity values obtained by the DPPH and ABTS methods and total monomeric anthocyanins were $r=0.92$ and 0.86 , respectively, and for the total phenolic compounds were $r=0.92$ and 0.99 , respectively, all significant at $1 \%$ probability of error. This high correlation between total phenolic compounds and antioxidant capacity results for the grape juices corroborates the findings of other studies (Lima et al., 2014; Silva et al., 2016), evidencing the biological properties responsible for the beneficial effects on the health of the consumer.

\subsection{Principal component analysis}

Principal components analysis (PCA) was performed on the dataset of the results for the eight grape juices, from the combination of four grape varieties and two rootstocks, for the 41 traits assessed (classical parameters, color attributes, organic acids, sugars, individual and total phenolic compounds and antioxidant capacity). The total variability was explained by seven principal components (PCs). Of these, the first two (PC1 and PC2) accounted for $73.43 \%$ of the total variation (Fig. 2).

PC1, which explained $45.25 \%$ of the total variation, was effective in separating the juices MX-766 and MX-572 from the others (Fig. 2A). The examination of the PC1 loadings (Fig. 2B) suggests that this separation is due to ABTS antioxidant capacity, total phenolic compounds, $\rho$-coumaric acid, cyanidin 3-glucoside, petunidin 3-glucoside, $t$ resveratrol, DPPH antioxidant capacity, quercetin, myricetin, epigallocatechin gallate, malvidin 3,5-diglucoside, color intensity, total monomeric anthocyanins, pelargonidin and isoquercetin. The PC1 scores and loadings suggest that the concentrations or values of these compounds were highest for 'IAC 138-22 Máximo' juices and lowest for 'Isabel Precoce' juices, which were located on the negative side of PC1 axis. The opposite was observed with regard to tartaric acid and chroma, which also made a notable contribution to the separation of the grape juices in PC1, however, with negative loadings. The PC1 scores and loadings suggest that all of these compounds were present at intermediate and similar levels in the 'BRS Carmem' and 'BRS Cora' juices, which were centered on the PC1 axis.

The PC2 accounted for $28.18 \%$ of the variability and was effective in separating the CR-572 and CR-766 juices from the others. The examination of the PC2 loadings indicates that this separation is mainly due to cyanidin 3,5-diglucoside, delphinidin 3-glucoside, cinnamic acid, gallic acid, titratable acidity, citric acid, malic acid and soluble solids. On the negative side of PC2, the loadings responsible for the separation corresponded to $\mathrm{pH}$ and the SS/TA ratio. The PC2 scores and loadings suggest juices CR-572 and CR-766 had low values for the $\mathrm{pH}$ and SS/TA ratio. However, these juices presented the other compounds mentioned in higher concentration than the 'Isabel Precoce', 'BRS Carmem' and 'IAC 138-22 Máximo' grape juices. Therefore, the principal components analysis was efficient in confirming the results presented herein.

\section{Conclusions}

The grape juices produced from new hybrid varieties presented different profiles of bioactive phenolic compounds and antioxidant capacity, which was due mainly to genetic characteristics of each grape variety. The 'IAC 138-22 Máximo' grape juices showed a higher content of individual and total anthocyanins, flavonols, $t$-resveratrol and total phenolic compounds and thus greater in vitro antioxidant capacity was measured compared with the other juices analyzed. In general, the 'BRS Cora' and 'BRS Carmem' juices provided similar values for phenolic content and antioxidant capacity. The high contents of phenolic compounds and color attributes presented by these three hybrids make them good alternatives to be used to produce grape juices with high quality, individually or in combination with other cultivars.

Several compounds were influenced by the rootstock, but with variations among the grape varieties. The 'IAC 766' rootstock favored 

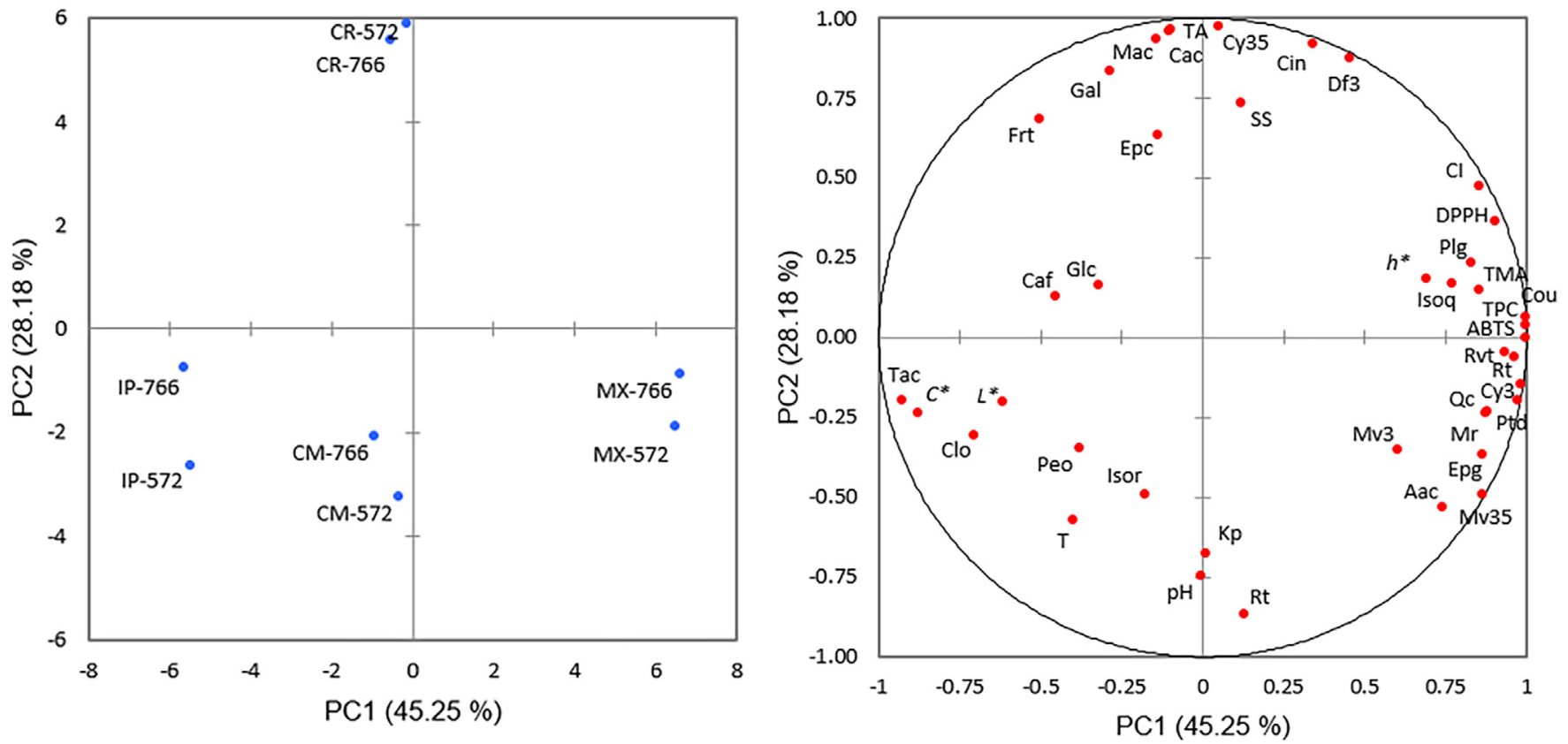

Fig. 2. Plots of the principal component analysis of chemical profile data for eight grape juices elaborated from Vitis labrusca and hybrid grape varieties grown on 'IAC 766' and 'IAC 572' rootstocks under tropical conditions in Brazil. PC1/PC2 scores (A) and loadings plot (B) accounted for 73.43\% of the total variation. Samples: Isabel Precoce [IP], BRS Carmem [CM], BRS Cora [CR], IAC 138-22 Máximo [MX], IAC 766 rootstock [766], IAC 572 rootstock 572. Trait abbreviations: soluble solids [SS], titratable acidity [TA], ratio [Rt], lightness $\left[L^{*}\right]$, chroma [ $\left.C^{*}\right]$, hue angle $\left[h^{\circ}\right]$, color intensity [CI], tint [T], tartaric acid [Tac], malic acid $[\mathrm{Mac}]$, citric acid [Cac], acetic acid [Aac], glucose [Glc], fructose [Frt], malvidin 3,5-diglucoside [Mv35], malvidin 3-glucoside [Mv3], cyanidin 3,5-diglucoside [Cy35], cyanidin 3-glucoside [Cy3], delphinidin 3-glucoside [Df3], peonidin 3-glucoside [Peo], pelargonidin 3-glucoside [Peg], petunidin 3-glucoside [Pet], kaempferol [Kp], myricetin [Mr], isorhamnetin [Isor], rutin [Rt], quercetin [Qc], isoquercetin [Isoq], gallic acid [Gal], caffeic acid [Caf], cinnamic acid [Cin], chlorogenic acid [Clo], $\rho-$ coumaric acid [Cou], trans-resveratrol [Rvt], (-)-Epicatechin gallate [Epc], (-)-Epigallocatechin gallate [Epg], total monomeric anthocyanins [TMA], total phenolics compounds [TPC], DPPH antioxidant capacity [DPPH], ABTS antioxidant capacity [ABTS].

the accumulation of sugars in the juices 'Isabel Precoce', 'BRS Cora' and 'IAC 138-22 Máximo'. This rootstock also contributed to the accumulation of anthocyanins and t-resveratrol in the 'IAC 138-22 Máximo' juices and of phenolic acids in the 'Isabel Precoce' juices.

\section{Conflict of interest}

The authors declare that they have no conflict of interest.

\section{Acknowledgments}

This work was supported by the Conselho Nacional de Desenvolvimento Científico e Tecnológico (CNPq, process n ${ }^{\circ}$ 140211/ 2015-2 and 305724/2018-5); and the Fundação de Amparo à Pesquisa do Estado de São Paulo (FAPESP, process $n^{\circ}$ 2015/16440-5). The authors are grateful to Centro Avançado de Pesquisa Tecnológica do Agronegócio de Seringueira e Sistemas Agroflorestais for the availability of the experimental area where this work was performed.

\section{References}

Ali, K., Maltese, F., Choi, Y., \& Verpote, R. (2010). Metabolic constituents of grapevine and grape-derived products. Phytochemistry Reviews, 9(3), 357-378.

Barcia, M. T., Pertuzatti, P. B., Gómez-Alonso, S., Godoy, H. T., \& Hermosín-Gutiérrez, I. (2014). Phenolic composition of grape and winemaking by-products of Brazilian hybrid cultivars BRS Violeta and BRS Lorena. Food Chemistry, 159, 95-105. https:// doi.org/10.1016/j.foodchem.2014.02.163.

Barros, L. B., Larissa, L., De Mio, M., Biasi, L. A., Di Profio, F., \& Reynolds, A. G. (2014). Use of HPLC for characterization of sugar and phenolic compounds in Vitis labrusca juice. Idesia, 32(2), 89-94.

Brasil (2000). Instrução Normativa nº 01, de 07 de janeiro de 2000. Regulamento técnico geral para fixação dos padrões de identidade e qualidade para polpa de fruta. Diário Oficial da República Federativa do Brasil, Seção, 1, 54-58.

Burin, V. M., Falcão, L. D., Gonzaga, L. V., Fett, R., Rosier, J. P., \& Bordignon-luiz, M. T.
(2010). Colour, phenolic content and antioxidant activity of grape juice. Ciência e Tecnologia de Alimentos, 30(4), 1027-1032.

Burin, V. M., Ferreira-Lima, N. E., Panceri, C. P., \& Bordignon-Luiz, M. T. (2014). Bioactive compounds and antioxidant activity of Vitis vinifera and Vitis labrusca grapes: Evaluation of different extraction methods. Microchemical Journal, 114, 155-163. https://doi.org/10.1016/j.microc.2013.12.014.

Camargo, U. A. (2004). 'Isabel Precoce': alternativa para a vitivinicultura brasileira. Comunicado Técnico [da] Embrapa Uva e Vinho, 54, 1-6.

Camargo, U. A., Maia, J. D. G., \& Ritschel, P. S. (2008). BRS Carmem. Nova cultivar de uva tardia para suco. Retrieved from Comunicado Técnico [da] Embrapa Uva e Vinho, $84,1-8$.

Coelho, E. M., da Silva Padilha, C. V., Miskinis, G. A., de Sá, A. G. B., Pereira, G. E., de Azevêdo, L. C., \& dos Santos Lima, M. (2018). Simultaneous analysis of sugars and organic acids in wine and grape juices by HPLC: Method validation and characterization of products from northeast Brazil. Journal of Food Composition and Analysis, 66, 160-167. https://doi.org/10.1016/j.jfca.2017.12.017.

Conde, C., Silva, P., Fontes, N., Dias, A. C. P., Tavares, R. M., Sousa, M. J., ... Gerós, H. (2007). Biochemical changes throughout grape berry development and fruit and wine quality. Food, 1(1), 1-22.

Corso, M., Vannozzi, A., Ziliotto, F., Zouine, M., Maza, E., Nicolato, T., ... Bonghi, C. (2016). Grapevine rootstocks differentially affect the rate of ripening and modulate auxin-related genes in Cabernet Sauvignon berries. Frontiers in Plant Science, 7, 1-14. https://doi.org/10.3389/fpls.2016.00069.

da Silva, M. J. R., Paiva, A. P. M., Pimentel, A., Sánchez, C. A. P. C., Callili, D., Moura, M. F., ... Tecchio, M. A. (2018). Yield performance of new juice grape varieties grafted onto different rootstocks under tropical conditions. Scientia Horticulturae, 241 194-200. https://doi.org/10.1016/j.scienta.2018.06.085.

Dani, C., Oliboni, L. S., Vanderlinde, R., Bonatto, D., Salvador, M., \& Henriques, J. A. P. (2007). Phenolic content and antioxidant activities of white and purple juices manufactured with organically- or conventionally-produced grapes. Food and Chemical Toxicology, 45, 2574-2580. https://doi.org/10.1016/j.fct.2007.06.022.

de Sá Borges, R., da Silva, G. A., Roberto, S. R., de Assis, A. M., \& Yamamoto, L. Y. (2013). Phenolic compounds, favorable oxi-redox activity and juice color of 'Concord' grapevine clones. Scientia Horticulturae, 161, 188-192. https://doi.org/10.1016/j. scienta.2013.07.011.

Embrapa (2006). Sistema Brasileiro de Classificação de Solos. Centro Nacional de Pesquisa de Solos (pp. 306). (2nd ed.). Rio de Janeiro: Embrapa Solos.

Glories, Y. (1984). La couler des vins rouges, $2^{\mathrm{a}}$ Partie Mesure, Origine et Interpretation. Connaissance de la Vigne et du Vin, 18(4), 253-271.

Granato, D., Carrapeiro, M. M., Fogliano, V., \& Van Ruth, S. M. (2016). Effects of geographical origin, varietal and farming system on the chemical composition and 
functional properties of purple grape juices: A review. Trends in Food Science \& Technology, 52, 31-48. https://doi.org/10.1016/j.tifs.2016.03.013.

Ibravin (2015). Pesquisa mapeia hábitos de consumo do suco de uva 100\%. Retrieved May 9, 2016, from http://www.ibravin.org.br/noticias/245.php.

Jackson, R. S. (2000). Chemical constituents of grapes and wine. In R. S. Jackson (Ed.). Wine Science (pp. 232-280). (2nd ed.). St.Catherines, Ontario: Academic Press.

Kim, Y. K., Guo, Q., \& Packer, L. (2002). Free radical scavenging activity of red ginseng aqueous extracts. Toxicology, 172, 149-156.

Koyama, R., de Assis, A. M., Yamamoto, L. Y., Borges, W. F. S., de Sá Borges, R. R., Prudêncio, S. H., \& Roberto, S. R. (2014). Exogenous abscisic acid increases the anthocyanin concentration of berry and juice from 'Isabel' Grapes (Vitis labrusca L.). HortScience, 49(4), 460-464.

Lee, J., Durst, R. W., \& Wrolstad, R. E. (2005). Determination of total monomeric anthocyanin pigment content of fruit juices, beverages, natural colorants, and wines by the $\mathrm{pH}$ differential method: Collaborative study. Journal of AOAC International, 88(5), 1269-1278.

Lee, J., \& Steenwerth, K. L. (2013). 'Cabernet Sauvignon' grape anthocyanin increased by soil conservation practices. Scientia Horticulturae, 159, 128-133. https://doi.org/10. 1016/j.scienta.2013.05.025.

Lima, M. S., Dutra, M. C. P., Toaldo, I. M., Corrêa, L. C., Pereira, G. E., Oliveira, D., ... Ninow, J. L. (2015). Phenolic compounds, organic acids and antioxidant activity of grape juices produced in industrial scale by different processes of maceration. Food Chemistry, 188, 384-392. https://doi.org/10.1016/j.foodchem.2015.04.014.

Lima, M. S., Silani, I. S. V., Toaldo, I. M., Corrêa, L. C., Biasoto, A. C. T., Pereira, G. E., ... Ninow, J. L. (2014). Phenolic compounds, organic acids and antioxidant activity of grape juices produced from new Brazilian varieties planted in the Northeast Region of Brazil. Food Chemistry, 161, 94-103. https://doi.org/10.1016/j.foodchem.2014.03. 109.

Liu, H., Wu, B., Fan, P., Li, S., \& Li, L. (2006). Sugar and acid concentrations in 98 grape cultivars analyzed by principal component analysis. Journal of the Science of Food and Agriculture, 1536(April 2005), 1526-1536. https://doi.org/10.1002/jsfa.

Maia, J. D. G., \& Camargo, U. A. (2012). O cultivo da videira Niágara no Brasil (1st ed.). Brasília, DF: Embrapa: Empresa Brasileira de Pesquisa Agropecuária.

Margraf, T., Santos, É. N. T., Andrade, E. F., Van Ruth, S. M., \& Granato, D. (2016). Effects of geographical origin, variety and farming system on the chemical markers and in vitro antioxidant capacity of Brazilian purple grape juices. Food Research International, 82, 145-155. https://doi.org/10.1016/j.foodres.2016.02.003.

Moreno-Montoro, M., Olalla-herrera, M., Gimenez-Martinez, R., Navarro-alarcon, M., \& Rufián-Henares, J. A. (2015). Phenolic compounds and antioxidant activity of Spanish commercial grape juices. Journal of Food Composition and Analysis, 38, 19-26. https://doi.org/10.1016/j.jfca.2014.10.001.

Nassur, R. C. M. R., Pereira, G. E., Alves, J. A., \& Lima, L. C. D. O. (2014). Chemical characteristics of grape juices from different cultivar and rootstock combinations.
Pesquisa Agropecuária Brasileira, 49(7), 540-545. https://doi.org/10.1590/S0100$204 X 2014000700006$.

Natividade, M. M. P., Corrêa, L. C., de Souza, S. V. C., Pereira, G. E., \& Lima, L. C. D. O. (2013). Simultaneous analysis of 25 phenolic compounds in grape juice for HPLC: Method validation and characterization of São Francisco Valley samples. Microchemical Journal, 110, 665-674. https://doi.org/10.1016/j.microc.2013.08. 010 .

OIV (2011). Recueil des methods internationals d'analyse des vins et des mouts (8th ed.). Paris: Assemblée Générale.

Padilha, C. V. S., Miskinis, G. A., Souza, M. E. A. O., Pereira, G. E., Oliveira, D., Bordignon-luiz, M. T., \& Lima, M. S. (2017). Rapid determination of flavonoids and phenolic acids in grape juices and wines by RP-HPLC/DAD: Method validation and characterization of commercial products of the new Brazilian varieties of grape. Food Chemistry, 228, 106-115. https://doi.org/10.1016/j.foodchem.2017.01.137.

Re, R., Pellegrini, N., Proteggente, A., Pannala, A., Yang, M., \& Rice-Evans, C. (1999). Antioxidant activity applying an improved ABTS radical cation decolorization assay. Free Radical Biology and Medicine, 26(9-10), 1231-1237. https://doi.org/10.1016 S0891-5849(98)00315-3.

Rebello, L. P. G., Lago-Vanzela, E. S., Barcia, M. T., Ramos, A. M., Stringheta, P. C., DaSilva, R., ... Hermosín-Gutiérrez, I. (2013). Phenolic composition of the berry parts of hybrid grape cultivar BRS Violeta (BRS Rubea $\times$ IAC 1398-21) using HPLC-DAD-ESIMS/MS. Food Research International, 54(1), 354-366. https://doi.org/10.1016/j. foodres.2013.07.024.

Silva, J. K., Cazarin, C. B. B., Correa, L. C., Batista, Â. G., Furlan, C. P. B., Biasoto, A. C. T. ... Maróstica Junior, M. R. (2016). Bioactive compounds of juices from two Brazilian grape cultivars. Journal of the Science of Food and Agriculture, 96, 1190-1996. https:// doi.org/10.1002/jsfa.7309.

Silva, F. L. N., Schmidt, E. M., Messias, C. L., Eberlin, M. N., Helena, A. C., \& Sawaya, F. (2015). Quantitation of organic acids in wine and grapes by direct infusion electrospray ionization mass spectrometry. Analytical Methods, 7, 53-62. https://doi.org/10. 1039/C4AY00114A.

Silva, M. J. R., Vedoato, B. T. F., Lima, G. P. P., Moura, M. F., Coser, G. M. A. G., Watanabe, C. Y., \& Tecchio, M. A. (2017). Phenolic compounds and antioxidant activity of red and white grapes on different rootstocks. African Journal of Biotechnology, 16(13), 664-671. https://doi.org/10.5897/AJB2016.15837.

Singleton, V. L., \& Rossi, J. A., Jr (1965). Colorimetry of total phenolics with phosphomolybidic-phosphotungstic acid reagents. American Journal of Enology and Viticulticulture, 16, 144-158.

Tang, X., Liu, J., Dong, W., Li, P., Li, L., Lin, C., ... Li, D. (2013). The cardioprotective effects of citric acid and L-malic acid on myocardial ischemia/reperfusion injury. Evidence-Based Complementary and Alternative Medicine, 2013, 1-11. https://doi.org/ $10.1155 / 2013 / 820695$. 